Bryant University

Bryant Digital Repository

Management Department Journal Articles

Management Faculty Publications and

Research

$3-2012$

\title{
Accessing Antecedents and Outcomes of RFID Implementation in Health Care
}

Pedro M. Reyes

Baylor University

Suhong Li

Bryant University

John K. Visich

Bryant University

Follow this and additional works at: https://digitalcommons.bryant.edu/manjou

\section{Recommended Citation}

International Journal of Production Economics, volume 136 issue 1, 2012.

This Article is brought to you for free and open access by the Management Faculty Publications and Research at Bryant Digital Repository. It has been accepted for inclusion in Management Department Journal Articles by an authorized administrator of Bryant Digital Repository. For more information, please contact dcommons@bryant.edu. 


\title{
Accessing Antecedents and Outcomes of RFID Implementation in Health Care \\ Pedro M. Reyes, Baylor University \\ Suhong Li, Bryant University \\ John K. Visich, Bryant University
}

\begin{abstract}
This research first conceptualizes, develops, and validates four new constructs for studying RFID in health care, including Drivers (Internal and External), Implementation Level (Clinical Focus and Administrative Focus), Barriers (Cost Issues, Lack of Understanding, Technical Issues, and Privacy and Security Concerns), and Benefits (Patient Care, Productivity, Security and Safety, Asset Management, and Communication). Data for the study were collected from 88 health care organizations and the measurement scales were validated using structural equation modeling. Second, a framework is developed to discuss the causal relationships among the above mentioned constructs and the established construct Performance. The research also compares perception differences regarding RFID implementation among the non-implementers, future implementers, and current implementers of RFID. It is found that both future implementers and current implementers consider RFID barriers to be lower and benefits to be higher compared to the non-implementers.
\end{abstract}

Subject Areas: Health Care, Radio Frequency Identification, Structural Equation Modeling, Technology Adoption 


\section{INTRODUCTION}

Prior to the Wal-Mart (June 2003) and the U.S. Department of Defense (July 30, 2004) mandates, radio frequency identification (RFID) had been flying below the business innovation radar. Since then, RFID empirical studies have been dominated by case studies and survey papers focused on adoption, benefits, and challenges of RFID implementations. Scholars in support of RFID have argued its potential to improve supply chain operational effectiveness and efficiency. These scholars propose RFID as a new alternative to existing tracking methods and a means to a wide range of previously cost-prohibitive internal control and supply chain coordination innovations (Bendoly et al., 2007; Reyes et al., 2007; Bottani and Rizzi, 2008; Rekik et al., 2008; Uckun et al., 2008). Regardless, given the external pressures to adopt coupled with the potential benefits of RFID, the adoption decision is for the most part based on managerial opinion (Vijayaraman and Osyk, 2006; Angeles, 2007; Bendoly et al., 2007; Reyes et al., 2007; Cannon et al., 2008; Angeles, 2009).

Yet, given the aforementioned research, empirical studies on the use of RFID in the health care industry have been limited. For example, a review of the academic literature on RFID from 1995-2005 by Ngai et al. (2008) identified only 1 health care article out of 85 articles analyzed. Ferrer et al. (2010) presented 21 cases studies on the application of RFID in services, yet there was only one health care case. Tzeng et al. (2008) studied 5 health care providers in Taiwan and created 7 propositions on how RFID can deliver business value to health care providers. However, these propositions need to be validated through empirical evidence.

Our research is further motivated by the U.S. Food and Drug Administration (FDA) strong recommendation for the pharmaceutical and health care industries to adopt RFID (FDA, 2004) and the increasing pressure to deliver high-quality patient care while controlling costs (LaGanga and Lawrence, 2007). Unfortunately, health care systems across the globe appear to be 
overwhelmed by spiraling costs, continuing quality concerns, increasing patient dissatisfaction, and shrinking resources (e.g., qualified doctors, nurses, and staff; space, budgets) (Athanassopoulos and Gounaris, 2001; Tucker, 2004; Goldstein, 2005; Wright et al., 2006; Umble and Umble, 2006; Liberatore and Nydick, 2008). However, some early RFID studies in the health care industry have shown or suggested that RFID implementations can reduce or mitigate these negative issues. For example, Advocate Good Shepherd Hospital, in Barrington, Illinois, was able to reduce annual inventory losses by ten percent through an RFID enabled inventory system (Glabman, 2004). In a successful "proof of application" study at the Elvis Presley Memorial Trauma Unit in Memphis, Tennessee Janz et al. (2005) found that RFID could assist in the control of workflow processes through the automatic capture of data on patient movements. Numerous RFID health care applications to improve patient treatment and safety have been proposed including: 1) tagging patients and their medications to ensure the correct drug and dosage are administered to the patient (McGee, 2004); 2) tracking the patients' care pathway to ensure the patient receives the correct procedures (Rogoski, 2006); 3) using RFID tagged blister packs to monitor patient compliance in taking their medication (Parks, 2003); 4) tracking blood to ensure its' usability in regards to perishability and accuracy (Roberts, 2003); and 5) identifying whether supplies and instruments had been sterilized before patient use (Miller, 1999). For additional overviews on health care applications of RFID see Wicks et al. (2006) and Correa et al. (2007).

Given the importance of RFID implementation in health care, more empirical studies are needed to understand the costs, benefits and challenges of RFID implementation so that useful guidance can be provided to health care organizations that are increasingly under pressure to implement RFID. However, there is no valid measurement instrument available in the literature 
to guide empirical research. This study develops four new constructs (Drivers, Implementation Level, Barriers and Benefits) and validates one existing construct (Performance) for studying RFID in health care. The findings from our analysis of 88 health care organizations provide strong support for the validity and reliability of most of our proposed constructs. In addition, this study develops a framework to discuss the causal relationship among the key constructs in RFID implementation in health care. This research also compares the perception differences regarding RFID Drivers, Barriers, Implementation Level, Benefits and Performance among the nonimplementers, future implementers and current implementers of RFID in health care.

The reminder of this paper is organized as follows. We first review previous literature for developing our constructs and framework. Next, we describe our methodology and data collection followed by our validation of constructs using structural equation modeling. We then present our data analysis. Finally, we offer implications and our conclusion to the study, followed by limitations of this study and future research.

\section{RESEARCH FRAMEWORK AND CONSTRUCTS DEVELOPMENT}

Figure 1 presents our research framework discussing the antecedents and outcomes of RFID implementation in health care. We identified major constructs in the RFID implementation including Drivers, Implementation Level, Barriers, Benefits and Performance (See Table 1). Drivers is defined as the level of pressure internally and externally to adopt RFID in order to improve a wide range of hospital process outcomes. Implementation Level is defined as the

process areas within the hospital that RFID is implemented. RFID Barriers are the extent to which possible obstacles reject or delay the implementation of RFID and benefits refer to the 
level of benefits that hospitals can receive from RFID implementation. Finally, Performance is defined as the performance position of the hospital with respect to their competitors.

Drivers is conceptualized as including Internal Drivers and External Drivers; Implementation Level includes Clinical Focus and Administrative Focus; Barriers includes four dimensions: Cost Issues, Lack of Understanding, Technical Issues and Privacy Concerns; Benefits has five dimensions: Patient Care, Productivity, Security and Safety, Asset Management and Communication; and Performance includes three dimensions: Cost, Quality and Financial.

Our construct development and the relationships between the constructs for the proposed model were based on three streams of research. The first research stream focused on empirical survey papers that tested relationships between the factors of quality, technology, leadership, and performance in the health care environment. The second research stream centered on RFID research in health care, while the third stream of research covered RFID review papers and empirical survey papers in the area of supply chain management. We first identified the measurement items for each proposed construct and discussed relationships between the constructs. We then developed a survey instrument that was designed to solicit feedback on the deployment of RFID in the health care environment. See Appendix A for the survey questions for each construct and subconstruct. We next discuss the supporting literature for each of the constructs and subconstructs, and we summarize our findings in Table 1. Then we discuss the relationships between the dimensions and present our research framework.

Insert Figure 1 Here

.................................

Insert Table 1 Here 


\subsection{Drivers}

The recent rapid growth in the interest and development of RFID technology was spurred by the tagging mandates made by Wal-Mart (O’Connor, 2005) and the United States (U.S.) Department of Defense (Collins, 2004). Under these mandates, suppliers were required to tag cases and pallets sent to distribution centers and supply depots. A survey by Vijayaraman and Osyk (2006) found that meeting the Wal-Mart compliance was the top reason supply chain firms were deploying RFID technology. No health care organization has an external mandate to implement tagging: however, the FDA recommendation does create adoption pressure (FDA, 2004). In order to assess whether or not health care organizations are under external pressure, we created a subconstruct to measure the impact external entities have in influencing a health care provider to implement RFID technology. From a review of the FDA report and papers by Wicks et al. (2006) and Correa et al. (2007) we identified patients, suppliers, the FDA, insurance companies and health maintenance organizations, regulatory groups, and competitors as External Drivers.

Since health care providers are not under a mandate to deploy RFID and there are numerous health care providers that have implemented RFID in their operations, it is reasonable to assume that these providers have deployed RFID for reasons that are internal to the organization. We reviewed the three empirical supply chain surveys conducted by Vijayaraman and Osyk (2006), Reyes et al. (2007) and Li et al. (2010) to identify internal reasons companies' implemented RFID technology. An analysis of the survey items identified several categories including visibility, efficiency, asset management, security, customer service, collaboration and cost reduction. We then used these categories to develop measurement items for the Internal Drivers. 


\subsection{Implementation Level}

Implementation Level is a new construct we develop to identify how RFID is used by the health care provider. Wicks et al. (2006) described several application areas for RFID, such as tracking physical items, controlling drug distribution to patients, tracking patient medication compliance, monitoring the patient's environment and movement in the facility, and tracking blood. Correa $e t$ al. (2007) identified health care specific uses of RFID, like patient identification and tracking, asset management and tracking, drug counterfeiting, inventory management, spare parts for surgery, blood and specimen bags, and tracking patient files. The use of RFID to track and monitor emergency room patients is discussed by Janz et al. (2005) and by Chao et al. (2007), while Schwaitzberg (2006) discussed RFID applications for surgery.

Based on the above discussion on the various uses of RFID in health care, we separate the Implementation Level of RFID into two subconstructs we name Clinical Focus and Administrative Focus. Clinical Focus refers to RFID implementations that have a direct impact on the patient's health and well being, while Administrative Focus refers to RFID implementations that have an indirect impact on patients.

\subsection{Barriers}

Table 2 lists barriers to the successful implementation of RFID that have been identified in the supply chain and health care literature. Universal standards refer to a lack of global standards for radio frequencies and protocols that will facilitate data exchange between various RFID users. Standards will also help to lower technology costs. Costs associated with RFID include the tags and readers, tag placement, facility/equipment redesign, training, and system maintenance. Software application issues refer to a lack of software to integrate and synchronize RFID data 
with the existing technology infrastructure, the filtering of noisy data (i.e., multiple reads of the same item), and analysis of that data. RFID technology problems include interference issues with metal, liquid, glass and moist environments which affects read rates and read accuracy, and the overall performance of the tags and readers. Privacy issues focus on the misuse of the tag to collect information on the person buying the tagged item or wearing a tag as an identification device. Privacy in health care is a very important issue and is regulated by the U.S. Department of Health \& Human Services Health Insurance Portability and Accountability Act (HIPAA) of 1996. The HIPAA Privacy Rule created national standards to protect the privacy of patients' medical records (HHS, 2006). Security issues deal with spoofing and hacking attacks to change the data on the tag. In the health care environment, unauthorized changes to a patients' tag might result in health complications or even death. Only two studies (Li \& Visich, 2006; Li et al., 2010) discussed the environmental problems of RFID readers and tags. Readers emit radiation when they transmit a signal creating a health risk to workers, and tags are non-biodegradable and may contain toxic metals. A lack of understanding about how RFID works, the possible benefits, and how to make the business case for RFID implementation were also found to be barriers. This category also includes calculating the return on investment and the payback period. Finally, the issue of labeling is important in health care because medication containers have little if any exterior space for tag placement.

\section{Insert Table 2 Here}

Vijayaraman and Osyk (2006) found that the top three RFID concerns were cost, a lack of understanding of the benefits, and integration issues. The top three RFID barriers identified by Reyes et al. (2007) were not applicable in our business, initial costs are too high, and expected 
benefits are not enough. The survey results of Li et al. (2010) were similar to Vijayaraman and Osyk (2006), where financial concerns was rated highest, followed by lack of a business case, and technology. Interestingly, privacy and environmental impact were the two lowest rated barriers. Therefore, for Barriers to implementing RFID, we developed the following four new subconstructs: Cost Issues; Lack of Understanding; Technical Issues; and Privacy Concerns.

\subsection{Benefits}

Table 3 lists benefits from the successful implementation of RFID that have been identified in the supply chain and health care literature. Track depicts knowing where an item is in the supply chain or for the health care profession knowing where a patient or employee is located. Trace is the ability to identify what went into a product (manufacturing inputs) and then knowing where the product has been. This facilitates recall management and the identification of unofficial 'grey' supply chains as well as the detection of counterfeit drugs. Inventory benefits cover a wide range of issues including control of inventory and expiration dates, the reduction of inventory, stock outs and shrinkage. In a health care environment, the control of inventory used to support surgical operations is critical so that all necessary items are available and none are left in the patient (Chao et al., 2007). Efficiency includes process automation, productivity improvements, and the reduction of labor costs. Communication is a key element in the supply chain and in health care for collaboration and planning, as well as the sharing of information between patients and health care providers. Asset management within the facility and the supply chain is critical for keeping asset costs down and yet still keep operations running. In the health care industry, assets used to provide services to patients are often expensive and need to be shared by providers. Error reduction is facilitated by the availability of accurate information. In the supply 
chain literature, this can help in the reconciliation of shipments, while in health care it can prevent the wrong medication being given to a patient. Finally, patient care aspects include customer service, patient safety, level of treatment, and compliance with medical practices.

Insert Table 3 Here

Vijayaraman and Osyk (2006) found that the top three sources of RFID cost savings (benefits) were reduced out-of-stocks, minimized inventory losses, and reduced labor cost due to less material handling. The top three RFID realized improvements identified by Reyes et al. (2007) were accuracy and availability of information, level of process automation, and level of customer service. In the survey by Li et al. (2010) those respondents who were pilot testing, implementing, or had implemented RFID indicated their top three motives as competitive decision, inventory management, and cost reduction in processes. For the construct Benefits we developed five new subconstructs: Patient Care; Productivity; Security \& Safety; Asset Management; and Communication.

\subsection{Performance}

Constructs for performance have been well established in the health care literature. In our research we measure the construct Performance with the three subconstructs Cost Performance, Quality Performance and Financial Performance. Cost Performance is related to holding down patient costs, and attaining high labor productivity and capacity utilization. Quality Performance is measured by indicators for clinical quality, patient satisfaction, and response to patient requests and complaints. Financial Performance focuses on market share growth, return on assets and investment, and operating profit. 
Li (1997) explored the relationships between hospital management practices and service quality performance, whereas $\mathrm{Li}$ and Collier (2000) investigated the role of technology and quality on hospital financial performance. Li and Benton (2003) measured the impact of hospital management decisions on cost performance and quality performance, while Li and Benton (2006) investigated the impact of hospital technology and nurse staffing management decisions on cost performance and quality performance. Patient satisfaction was measured as an outcome by Meyer and Collier (2001) and by Marley et al. (2004). All three performance constructs were used in a structural model by $\mathrm{Li}$ et al. (2002) who found that hospital quality performance indirectly affected hospital financial performance and that cost performance directly affected hospital financial performance.

\subsection{Research Framework}

Based on the above discussion of the constructs, we propose that Internal Drivers and External Drivers will have a positive impact on the Implementation Level of RFID, which in turn will have a positive impact on RFID Benefits, leading to a positive impact on Performance. In addition, RFID Barriers are proposed to be negatively related to RFID Implementation Level in health care. The following section will provide a brief literature support for the proposed research framework.

External drivers of change in the health care industry include shifts in demand and customer expectations, dynamic markets and advances in technology, particularly in the area of information technology (Abernethy and Lillis, 2001; Carmen et al., 1996, and Bouwens and Abernethy, 2000). And, it is well known that there is intense pressure on health care organizations from outside agencies, such as regulatory groups and insurance companies, to 
lower costs and improve performance. For example, medical errors cost the U.S. Medicare program more than $\$ 8.8$ billion annually (Business Wire, 2008). In order to secure the pharmaceutical supply chain from counterfeit drugs and terrorist attacks the FDA has identified several implementation areas for RFID technology including the tracking of drugs through the supply chain, the management of drug inventory, and the correct dispensement of drugs to the patient (FDA, 2004). Based on these trends and events we propose that External Drivers will have a positive impact on RFID Implementation Level.

The Institute of Medicine has estimated that between 44,000 to 98,000 patients die from medical errors annually in the U.S. These errors are usually are drug-related but also include incorrect patient diagnostics, equipment failures, and misinterpretation of medical orders (Crane and Crane, 2006). Medical errors are also caused by a lack of communication among and between all levels within the health care organization (Tang and Lansky, 2005), and hospital residents cited overwork, inadequate supervision and handoff problems as the most common causes for medical errors (Jagsi et al., 2005). The implementation of RFID technology can help to reduce medical errors by automatically ensuring patients receive the correct drug and dosage (McGee, 2004), are on the correct care pathway (Murphy, 2003), and RFID can be used to monitor the patients environment and movement within the facility (Hoska, 2004). Health care organizations use a systems approach to promote patient safety, reduce medical errors, and increase patient satisfaction Kohn et al. (2000) and physicians utilize a variety of quality programs as their primary approach to improve quality (Martin, 2007). Therefore, Internal Drivers will have a positive impact on RFID Implementation Level.

The implementation of RFID in a health care facility poses numerous challenges. For example, Hoska (2004) estimated that a 1000-bed hospital would need to tag 20,000 items per 
day, while Becker (2004) estimated that an 800-bed hospital would need to tag approximately 15,000 doses of medication daily. Janz et al. (2005) found that an RFID system to track patients in an emergency room created a significant amount of noise and 'dirty data' that needed to be filtered before the data could be used for analysis. And, health care organizations need to be complaint with HIPPA in order to ensure the privacy rights of patients (Fenner, 2004). Clearly, the number and severity of obstacles encountered will affect the implementation level of RFID and we propose that Barriers will have a negative impact on Implementation Level.

Numerous benefits have been reported from the implementation of RFID in health care. Holy Name Hospital in Teaneck, New Jersey found that RFID-tagged of equipment could be located quicker and was more fully utilized, which reduced equipment rental costs (Glabman, 2004). Patient care can be improved through higher accuracy in medicine dispensement (Klein, 2003), in patient compliance (Parks, 2003), and in the reduction of medical errors (Klein, 2003). Approximately $70 \%$ of the respondents to a BearingPoint Study (Editorial, 2006) identified patient safety as the most important RFID implementation benefit. Therefore, Implementation Level will have a positive impact on Benefits.

The Li et al. (2010) survey found that organizations with RFID experience (piloting, implementing, implemented) rated competitive decision as the highest of six categories for the motivation to implement RFID technology, while respondents considering RFID implementation within two years rated competitive advantage the third highest motivation. Competitive advantage was measured using the survey items strategic initiative and competitive advantage. Visich et al. (2009) conducted a review of empirical evidence of RFID in the supply chain, and using the business process framework of Mooney et al. (1996) proposed that for managerial processes RFID has the potential to facilitate transformational effects when the process is 
reengineered to significantly improve competitive capability. And, Spekman and Sweeny (2006) noted that "the early adopters will reap a strategic benefit from deploying RFID" (p.750). Based on this discussion we hypothesize that Benefits from RFID deployment will have a positive impact on organizational Performance.

\section{RESEARCH METHODOLOGY AND DATA COLLECTION}

The research methodology used is based on empirical data collected through a web-based questionnaire survey of health care professionals. We focused on the health care industry first to eliminate perplexing results across industries, second because the U.S. Food and Drug Administration has strongly recommended that the pharmaceutical and health care industries adopt RFID, and finally because of the innovative opportunities (both patient focus and economic focus) that RFID can provide to the health care industry.

Guided by our literature review, we developed a survey instrument to measure and test the relationships between the constructs. These survey items were reviewed by five health care professionals and five academics. Based on their feedback we made minor changes to the survey instrument. We then e-mailed the survey to 1,000 health care professionals. Approximately 900 e-mails were successfully sent to top-level managers at hospitals across the United States asking them to access the survey link. Between March and July 2008, and after three e-mail requests, a total of 88 useable responses were collected giving a response rate of $9.8 \%$. We also received more than 100 e-mail replies stating: their company is not considering RFID; that company policy forbids participation in such surveys; respondent did not have time to complete the survey; or requesting to be removed from the e-mail list. 


\section{INSTRUMENT DEVELOPMENT AND VALIDATION}

\subsection{Item Generation}

The basic requirement for a good measurement is content validity, which means that the measurement items in an instrument cover the major content of a construct (Churchill, 1979). Content validity is usually achieved through a comprehensive literature review and interviews with practitioners and academicians. The items for Drivers, Implementation Level, Barriers, Benefits and Performance were generated based on previous literature as discussed in Section 2 Research Development and Constructs Development. Items that measure Performance were adopted from Li et al. (2002). The items for these five instruments are listed in Appendix A. All survey items were measured using a 7-point Likert scale.

\subsection{Large-scale Data Analysis}

While the number of useable responses (88) and the response rate (9.8\%) were less than desired, the makeup of respondent pool was considered excellent. As seen in Table 4, a majority of the respondents are top level managers, with 30\% (27) of the respondents CEOs and 19\% (17) of them vice presidents. A few respondents identified themselves as $\mathrm{COO}, \mathrm{CNO}, \mathrm{CFO}$ or $\mathrm{CIO}(8 \%$, 7) and 28\% (25) are at the director level. These individuals are expected to have a broad view of RFID implementation in their organization and this meets our objective of collecting information at the organizational level. Hospital location (urban $(47 \%, 40)$ and rural $(53 \%, 46))$ as well as affiliation (system affiliated $(56 \%, 49)$ and stand-alone $(44 \%, 38))$ are represented about equally. In addition, 66\% (58) of the respondents work at large hospitals (>500 employees) and a significant majority are not-for-profit $(93 \%, 79)$ and are not teaching hospitals $(76 \%, 66)$.

Insert Table 4 Here 


\subsection{Instrument Assessment Methodology}

Following the guidelines of Bagozzi (1980) and Bagozzi and Phillips (1982), the following measurement properties are considered important for assessing the measures developed in this paper: (1) content validity, (2) internal consistency of operationalization (unidimensionality and reliability), (3) convergent validity, and (4) discriminant validity.

\subsubsection{Content Validity}

Content validity depends on how well the researchers create measurement items to cover the domain of the variable being measured (Nunnally, 1978). The evaluation of content validity is a rational judgmental process not open to numerical evaluation. The usual method of ensuring content validity is an extensive review of literature for the choice of the items and the solicitation of inputs from practitioners and academic researchers on the appropriateness, completeness, etc. The content validity of the constructs in this paper was established through extensive review and input from health care professionals and academicians.

\subsubsection{Unidimensionality}

Unidimensionality can be defined as the existence of one latent trait or construct underlying a set of measures (McDonald, 1981; Hattie, 1985). This research will thus use structural equation modeling (SEM) to test unidimensionality of each construct. We use multiple fit criteria to test for unidimensionality and reduce any measuring biases inherent in different measures. Two goodness of fit indices were used: goodness-of-fit (GFI) and comparative fit index (CFI). The values of those fit indexes above 0.90 or higher suggest no evidence of a lack of unidimensionality. 
RFID Drivers was represented by 2 dimensions and 16 items (see Appendix A). A single factor LISREL measurement model is specified for each dimension of RFID Drivers. Following Sethi and King (1994), iterative modifications were made for each of the constructs by observing modification indices and coefficients to improve key model fit statistics. Further, as recommended by Joreskog and Sorbom (1989), only one item was altered at a time to avoid over-modification of the model. This iterative process continued until all model parameters and key fit indices met recommended criteria. If the constructs have less than 4 items, model fit statistics could not be obtained. In these cases, a two-factor model was tested by adding the items of another construct. The items of another construct are added only to provide a common basis for comparison and to keep items in sufficient number so that model fit statistics could be obtained. The same methodology was applied to the other four constructs, including Implementation Level, Barriers, Benefits, and Performance. The final results are summarized in Table 5. The table presents the number of items measuring each construct, and statistics for assessing the goodness of fit of the measurement model. It can be seen that half the GFI values are above 0.90 and the other half a little below 0.90 . This may be caused by the small sample size. All CFI values are 0.90 or above indicating the unidimensionality of all constructs. The items removed in the final instrument are identified by an asterisk in Appendix A.

\subsubsection{Reliability}

Insert Table 5 Here

Traditionally, the Cronbach $\alpha$ coefficient (Cronbach, 1951) has been used to evaluate reliability. A scale is found to be reliable if $\alpha$ is 0.70 or higher (Nunnally, 1978). However, it has been noted that Cronbach $\alpha$ uses restrictive assumptions regarding equal importance of all indicators and the measure of reliability can be biased. An alternate composite reliability measure has been 
suggested (Werts et al., 1974). This reliability measure $\rho_{c}$ for an underlying theoretical dimension A, can be calculated as follows:

$$
\rho_{c}=\left(\sum_{i=1}^{p} \lambda_{i}\right)^{2} \operatorname{Variance}(\mathrm{A}) /\left(\left(\sum_{\mathrm{i}=1}^{\mathrm{p}} \lambda_{\mathrm{i}}\right)^{2} \operatorname{Variance}(\mathrm{A})+\sum_{i=1}^{p} \theta_{\delta}\right)
$$

where $\rho_{c}$ is the composite measure reliability, $\mathrm{p}$ is the number of indicators, $\lambda_{\mathrm{i}}$ is the factor loading which relates item $I$ to the underlying theoretical dimension $A$, and $\theta_{\delta}$ is error variance. When $\rho_{c}$ is greater than 0.50 it implies that the variance captured by the factor is more than that captured by the error components (Bagozzi, 1981). Bagozzi (1981) and Werts et al. (1974) suggest using $\rho_{c}$ in conjunction with Cronbach alpha. The calculated values for Cronbach's alpha were very similar to Werts-Linn-Jorsekog coefficient $\left(\rho_{c}\right)$. In Table 6 we report $\rho_{c}$ and Cronbach's alpha for each subconstruct. Note that all coefficients are 0.85 or greater, indicating good construct reliability of all the subconstructs.

Insert Table 6 Here

\subsubsection{Convergent and Discriminant Validity}

A factor analysis was conducted for each of the five constructs using principal components as means of extraction and varimax as method of rotation. Factor analysis is useful in providing some evidence of discriminant and convergent validity of measurement items (Segars and Grover, 1993). Items with good measurement properties should exhibit high factor loadings on the latent factor of which they are indicators (convergent validity), and small factor loadings on the factors that are measured by differing sets of indicators (discriminant validity). The results of the factor analysis for each of the five constructs are shown in Tables 7-11. For simplicity, only loadings above 0.40 were displayed. It can be seen that all items loaded on their respective 
factors and there were no items with cross-loadings greater than 0.50 . The results of factor analysis provide primitive support for convergent and discriminant validity of the constructs.

Insert Table 7 Here

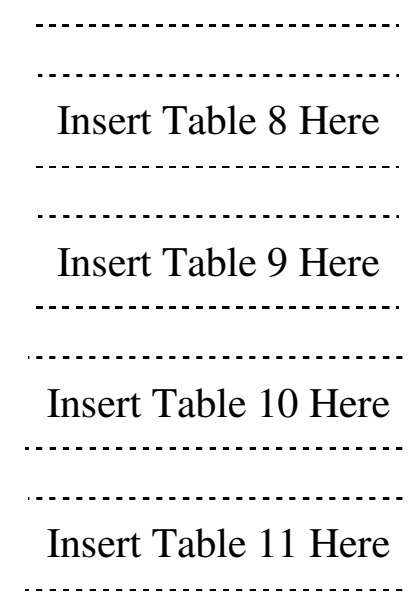

\section{DATA ANALYSIS}

The respondents were asked to indicate the state of RFID deployment in their organizations in the survey. The surveyed organizations were then classified into three groups: non-implementers, future implementers and current implementers. Non-implementers include organizations who do not have plans to implement RFID within the next two years, future implementers plan to implement RFID within the next two years and current implementers are organizations that are currently pilot testing, implementing or have completed implementation of RFID technology. Among all the organizations, 50\% (44 respondents) are non-implementers, 35\% (31 respondents) belong to future implementers and the rest $(15 \%, 13$ respondents) are current implementers.

This section will first test the causal relationship proposed in Figure 1, followed by the comparison of RFID Implementation Level between future and current implementers and then comparison of RFID Drivers, Barriers, Benefits and Performance among non-implementers, future implementers and current implementers. 


\subsection{Results for the Proposed Research Framework}

Structural equation modeling was used to test the proposed relationships in Figure 1. We split Drivers into two constructs in order to better understand what motivates health care providers to adopt RFID technology. We removed the non-implementers from the analysis since they do not plan to implement RFID and are thus irrelevant in the analysis.

Figure 1 displays the path diagram resulting from the structural modeling analysis using AMOS. The model fit measures are: GFI $=.91, \mathrm{CFI}=.85, \mathrm{NFI}=.80$ (normed fit index), and RMSR=.122 (root mean square residual). GFI is above the recommended value of .90; CFI and NFI are at or above .80 . However, RMSR is above the suggested maximum value of .05 and this result may be due to the very small sample size (44) since RMSR tends to increase as the sample size decreases (Anderson \& Gerbing, 1984). The results show that except for the link between External Drivers and Implementation Level, the other relationships are found to be significant.

The lack of a significant link between External Drivers and Implementation Level indicates that health care organizations are not under pressure from external entities to adopt RFID technology. The significant positive link between Internal Drivers and Implementation Level shows that health care organizations are implementing RFID on their own initiative to improve hospital process outcomes. This is a good outcome as it indicates hospitals are being proactive in the deployment of RFID. In contrast to the proposed negative relationship, Barriers are found to be positively related to the Implementation Level. This was an unexpected result as we hypothesized that the greater the barriers the lower the likelihood of RFID implementation. There are several possible explanations for this result. First, barriers may not discourage the implementation of RFID because organizations feel the anticipated or derived benefits will be worth the effort to overcome the barriers. Even though organizations are aware of various 
barriers to the RFID implementation, they still want to implement it because of anticipated benefits from the implementation. Second, our respondent pool consisted of a significant number of high level managers and there could be an expectation that even though barriers are high, the employees tasked with implementing RFID will find a way around the barriers. Third, it is possible that higher levels of multiple RFID implementations create higher levels of barriers. Future research may validate this finding.

The results support our propositions that Implementation Level has a positive relationship with Benefits, and that Benefits has a positive impact on Performance. Both of these paths are significant, supporting our propositions regarding them. This makes sense as hospitals would most likely implement RFID in processes where they expect to receive benefits from the deployment, and these benefits should improve overall performance.

\subsection{Comparison of RFID Implementation Level between Current and Future Implementers}

For the current and future implementers, the respondents were asked to indicate the actual or anticipated level of RFID implementation in various areas in their organizations. The results are show in Table 12.

Insert Table 12 Here

Table 12 shows that top five RFID applications for the current implementers are track: medical equipment (4.75); medication dispensing (3.49); MRO inventories (maintenance, repair, operating) (3.45); hospital beds (3.31); and emergency room patients (3.23). For the future implementers, the top five applications are track: infants (4.16); medical equipment (3.97); medication dispensing (3.77); patient medication usage (3.61); and surgical operations (tools, 
sponges etc) (3.48). It can be seen that tracking medical equipment and track medication dispensing belong to the top five in these two groups. In addition, the current implementers group focused on both clinical and administrative areas by using RFID to track emergency room patients, MRO inventory, and hospital beds. The future implementers focused primarily on clinical areas and plan to use RFID to track infants, patient medication usage and surgical operations. The only administrative focus implementation to be in the top ten for future implementers was track hospital beds, which was ranked $8^{\text {th }}$.

Table 12 also show that except for track medical equipment, track administrative equipment, track doctor, and track administrative personnel, the future implementers have a higher perceived implementation level in most areas than the actual implementation level rated by the current implementers group. This may reflect a gap between perception and reality. Companies may have a higher expectation for the level of RFID implementation than what will be actually implemented later. It is interesting to note that current implementers scored track medical equipment the highest implementation level for both groups of implementers.

\subsection{Comparison of RFID Drivers, Barriers, Benefits, and Performance}

Analysis of Variance (ANOVA) tests were used to compare the perception difference among the non-implementers, future implementers, and current implementers regarding RFID Drivers, Barriers, Benefits and Performance. The results are shown in Table 13 and Table 14.

Insert Table 13 Here

Insert Table 14 Here 
The results show that significant differences exist in the respondents' perception regarding RFID Barriers (Cost, Lack of Understanding, and Technical Issues) and Benefits (Patient Care and Productivity) among the three groups. T-tests were conducted to see where differences between the three groups existed in each construct and the results are shown in Table 15. For the Barrier Cost, non-implementers have a significantly higher mean than future implementers, and future implementer have a significantly higher mean than the current implementers. Regarding the Barrier Lack of Understanding, current implementers have a significantly lower mean than nonimplementers and future implementers. For the Barrier Technical Issues, non-implementers have a significantly higher mean than current implementers and future implementers. For the Benefit Patient Care, future implementers consider Patient Care as a greater benefit of RFID implementation than non-implementers. In term of the Benefit Productivity, non-implementers have a significantly lower mean than current and future implementers. In sum, it can be seen that there exists more similarity regarding RFID Barriers and Benefits between current implementers and future implementers, and more difference between non-implementers and current/future implementers. Compared to non-implementers, future and current implementers consider RFID Barriers to be lower and Benefits to be higher (See Chart 1). In addition, no significant differences were found in RFID Drivers and Performance among the three groups.

Insert Table 15 Here

Insert Chart 1 Here

Finally we note two items of interest in Table 13. First, non-implementers have the highest mean for External Drivers while current implementers have the lowest mean. The opposite 
occurs for Internal Drivers where current implementers have the highest mean and nonimplementers have the lowest mean. Second, for each of the four subconstructs for Barriers the mean declines from non-implementers to future implementers to current implementers. This indicates that non-implementers have a pessimistic perception regarding the actual barriers to RFID implementation.

\section{IMPLICATIONS AND CONCLUSIONS}

In this research we utilized three research streams to design a research framework and survey instrument to measure and study RFID in health care. For our survey instrument we developed four new constructs (Drivers, Implementation Level, Barriers and Benefits) and we utilized one existing construct from the literature (Performance). Next, we conducted a small pilot test with practitioners and academicians and based on their appraisal we refined the survey instrument. We distributed the survey instrument to health care professionals and we then completed a rigorous statistical analysis to determine the validity and reliability of the constructs.

The results of our data analysis provide strong support for content validity, unidimensionality, reliability and convergent validity for all five constructs. This research represents a first attempt to develop and validate a set of constructs for studying RFID implementation in health care at the organizational level using a rigorous methodology. The instrument developed in this paper will be of use to researchers for further studies of RFID implementation in health care.

The results of our research also show the importance of RFID implementation to the health care organization. The research indicates that managers believe the implementation of RFID in health care could lead to many benefits including improved patient care, improved patient 
security and safety, and finally improved organizational performance. The results also show that RFID deployment in health care is driven by internal factors, not external pressure. This result is expected since health care organizations are not under a mandate to implement RFID; their decision to adopt RFID must be driven by internal factors, such as visibility, efficiency, asset management, security, patient service, collaboration and cost reduction.

The results also indicate that perception differences exist between the non-implementers, future implementers and current implementers regarding RFID. Non-implementers consider RFID barriers to be higher and benefits to be lower than the other two groups. This may be caused by a lack of understanding of RFID technology. To increase the adoption of RFID, more studies on RFID in health care need to be done to help health care organizations better understand the drivers, benefits, barriers and implementation issues of RFID.

While these results appear exciting in that our analysis provides a strong assessment of the antecedents and outcomes of RFID implementation in health care, the study suffered from a small sample size because of the early stage of RFID development. In addition, these 88 responses were divided into three categories, where non-implementers were the largest group (44 responses), while there were 31 future implementers and only 13 implementers. As with all survey studies, our scope limitation prevents a complete story (for our sample set).

While RFID technology is being pushed by retail giants like Wal-Mart and touted as having great potential for reducing costs and improving customer service - the focus has been mostly on the supply chain. Because of this supply chain focus, health care professionals were not aware of the applications that could be used in service operations. Hence, the numerous e-mail replies stating: "our company is not considering RFID". We believe this lack of awareness in the field 
led to the limited sample size. Future research should validate the constructs developed in this paper using a larger sample size.

RFID adoption in health care is still in the early stages. Future study can also include additional constructs in the implementation of RFID in health care. For example, how does top management support and workforce development impact the implementation level of RFID? Future study can also look at the impact of contextual factors (organization size, culture, geographic location, etc.) on RFID implementation or how the various items for a construct impact a linked construct. For example, does substantial tracking implementation lead to improvements in patient care and security and safety. If a larger survey sample can be obtained, it would be possible to develop separate structural models for future implementers and current implementers. Another area of study is the impact of barriers on implementation level to help explain why our results showed an unexpected positive relationship between Barriers and Implementation level.

\section{REFERENCES}

Abernethy, M. \& Lillis, A. (2001). Interdependencies in organization design: A test in hospitals. Journal of Accounting Management Research, 13(1), 107-129.

Anderson, J. C., \& Gerbing, D. W. (1984). The effect of sampling error on convergence, improper solutions, and goodness of indices for maximum likelihood confirmatory factor analysis. Psychometrika, 49, 155-173.

Angeles, R. (2007). An empirical study of the anticipated consumer response to RFID product item tagging. Industrial Management \& Data Systems, 107(4), 461-483.

Angeles, R. (2009). Perceptions of the importance of absorptive capacity attributes as they relate to radio frequency identification implementation by firms anticipating radio frequency identification use. International Journal of Management and Enterprise Development, 6(1), 88-117.

Athanassopoulos, A., \& Gounaris, G. (2001). Assessing the technical and allocative efficiency of hospital operations in Greece and its resource allocation implications. European Journal of Operational Research, 133(2), 416-431.

Bagozzi, R. P. (1980). Causal Models in Marketing. New York, NY: Wiley. 
Bagozzi, R.P. (1981). An examination of the validity of two models of attitude. Multivariate Behavioral Research, 16(3), 21-37.

Bagozzi, R.P., \& Phillips, L.W. (1982). Representing and testing organizational theories: a holistic construct. Administrative Science Quarterly, 27(3), 459-489.

Bagozzi, R.P., \& Phillips, L.W. (1991). Assessing construct validity in organizational research. Administrative Science Quarterly, 36(3), 421-458.

Becker, C. (2004). A new game of leapfrog?. Modern Healthcare, 34(28), 38.

Bendoly, E., Citrus, A., \& Konsynski, B. (2007). Internal infrastructural impacts on RFID perception and commitment: knowledge, operational procedures, and information-processing standards. Decision Sciences, 38(3), 423-449.

Bentler, P.M., \& Bonett D.G. (1980). Significance tests and goodness of fit in the analysis of covariance structures. Psychological Bulletin, 88, 588-606.

Bollen, K.A., \& Long, J.S. (1993). Testing Structural Equation Models. Newbury Park, CA: Sage Publications.

Bottani, E. \& Rizzi, A. (2008). Economical assessment of the impact of RFID technology and EPC system on the fast-moving consumer goods supply chain. International Journal of Production Economics, 112(2), 548-569.

Bouwens, J. \& Abernethy, M. (2000). The consequences of customization on management accounting system design. Accounting, Organizations and Society, 25(3), 221-241.

Business Wire (2008). Medical errors cost U.S. $\$ 8.8$ billion, result in 238,337 potentially preventable deaths, according to HealthGrades study. Business Wire, April 8.

Byrne, B.M. (1989). A primer of LISREL: basic applications and programming for confirmatory factor analytic model. New York, NY: Springer-Verlag.

Campbell, D.T., \& Fiske, D.W. (1959). Convergent and discriminant validation by the multitraitmultimethod matrix. Psychological Bulletin, 56, 81-105.

Cannon, A., Reyes, P.M., Frazier, G., \& Prater, E. (2008). RFID in the contemporary supply chain: multiple perspectives on its benefits and risk. International Journal of Operations \& Production Management, 28(5), 433-545.

Carman, J., Shortell, S., Foster, R. \& Hughes, E. (1996). Keys for successful implementation of total quality management in hospitals. Healthcare Management Review, 21(1), 48-61.

Chao, C.C., W.Y. Jen, Y.P Chi, B. Lin (2007). Improving patient safety with RFID and mobile technology. International Journal of Electronic Healthcare, 3(2), 175-192.

Chau, P.Y.K. (1997). Reexamining a model for evaluating information center success using a structural equation modeling approach. Decision Sciences, 28(2), 309-334.

Churchill, G.A. (1979). A paradigm for developing better measures of marketing constructs. Journal of Marketing Studies, 16, 12-27.

Collins, J. (2004). DOD updates RFID policy. RFID Journal, April 1, accessed July 13, 2004, available at http://www.rfidjournal.com/article/articleprint/856/-1/1/ 
Correa, F.A., Gil, M.J.A., \& Redin, L.B. (2007). RFID and health management: is it a good tool against system inefficiencies. International Journal of Healthcare Technology Management, 8(3-4), 268-297.

Crane, J. \& Crane, F. (2006). Preventing medication errors in hospitals through a systems approach and technological innovation: A prescription for 2010. Hospital Topics, 84(4), 3-8.

Cronbach, L., (1951). Coefficient alpha and the internal structure of tests. Psychometrika, 16, 297-334.

Editorial (2006). BearingPoint, Inc; Larger healthcare organizations more likely to use RFIDs, survey shows. Medical Device Law Weekly, January 1.

FDA (2004). Combating counterfeit drugs-a report of the Food and Drug Administration. U.S. Food and Drug Administration, accessed October 1, 2007, available at http://www.fda.gov/oc/initiatives/counterfeit/report 02_04. html

Fenner, M. (2004). Health care goes high tech. Card Technology, July/August, 38-45.

Ferrer, G., Dew, N., \& Apte, U. (2010). When is RFID right for your service? International Journal of Production Economics, 124(2), 414.

Glabman, M. (2004). Room for tracking: RFID technology finds the way. Materials Management in Health Care, May, 26-38.

Goldstein, S., \& Naor, M. (2005). Linking publicness to operations management practices: a study of quality management practices in hospitals. Journal of Operations Management, 23(2), 209-228.

Hartwick, J., \& Barki, H. (1994). Explaining the role of user participation in information systems use. Management Science, 40(4), 440-465.

Hattie, J. (1985). Methodology review: assessing unidimensionality of tests and items. Applied Psychological Measurement, 9, 139-164.

HHS (2006). Health information privacy: What does the HIPAA Privacy Rule do?. U.S. Department of Health and Human Services, accessed September 20, 2009, available at http://www.hhs.gov/ocr/privacy/hipaa/faq/about/187. html

Hosaka, R. (2004). Feasibility study of convenient automatic identification system of medical articles using LF-band RFID in hospital. Systems and Computers in Japan, 35(10), 571-578.

Jagsi, R., Kitch, B., Weinstein, D., Campbell, E., Hutter, M. \& Weissman, J. (2005). Residents report on adverse events and their causes. Archives of Internal Medicine, 165, Dec. 12/26, 2607-2613. Downloaded from www.archinternmed.com on October 8, 2008.

Janz, B.D., Pitts, M.G., \& Otondo, R.F. (2005). Back to future with RFID, lessons learned-some old, some new. Communications of the AIS, 15(7), 132-147.

Joreskog, K.G. (1971). Simultaneous factor analysis in several populations. Psychometrika, 57, 409-426.

Joreskog, K.G., \& Sorbom, D. (1989). LISREL 7 users' reference guide. Chicago, IL: Scientific Software Inc.

Klein, P. (2003). It's innovation that counts. Optimize, October, 99-102. 
Kohn, L., Corrigan, J. \& Donaldson, M. (2000). To Err is Human: Building a Safety Health System. Committee on Quality Healthcare in America, Institute of Medicine, National Academic Press, Washington, D.C.

LaGanga, L., \& Lawrence, S (2007). Clinical overbooking to improve patient access and increase provider productivity. Decision Sciences, 38(2), 251-276

Li, L. (1997). Relationships between determinants of hospital quality management and service quality performance - a path analytic model. OMEGA, 25(5), 535-545.

Li. L., \& Benton, W.C. (2003). Hospital capacity management decisions: emphasis on cost control and quality enhancements. European Journal of Operational Research, 146(3), 596614.

Li, L., \& Benton, W.C. (2006). Hospital technology and nurse staffing management decisions. Journal of Operations Management, 24(5), 676-691.

Li, L., Benton, W.C., \& Leong, K. (2002). The impact of strategic operations management decisions on community hospital performance. Journal of Operations Management, 20(4), 389-408.

Li, L., \& Collier, D. (2000). The role of technology and quality on hospital financial performance: an exploratory analysis. International Journal of Service Industry Management, 11(3), 202-224.

Li, S., Godon, D. \& Visich, J.K. (2010). An exploratory study of RFID implementation in the supply chain. Management Research Review, 33(10), 1005-1015.

Li, S. \& Visich, J.K. (2006). Radio frequency identification: supply chain impact and implementation challenges. International Journal of Integrated Supply Management, 2(4), 407-424.

Liberatore, M., \& Nydick, R. (2008). The analytic hierarchy process in medical and health care decision making: A literature review. European Journal of Operational Research, 189(1), 194-207.

Marley, K., Collier, D., \& Goldstein, S. (2004). The role of clinical and process quality in achieving patient satisfaction in hospitals. Decision Sciences, 35(3), 349-369.

Martin, W.F. (2007). Quality models: Selecting the best model to deliver results. The Physician Executive, 33(3), 24-31.

McDonald, R.P. (1981). The dimensionality of tests and items. British Journal of Mathematical and Statistical Psychology, 34, 100-117.

McGee, M. (2004). E-health revives health-care IT. Information Week, September 20, 101-105.

Meyer, S. \& Collier, D. (2001). An empirical test of the causal relationships in the Baldrige health care pilot criteria. Journal of Operations Management, 19(4), 403-425.

Miller, M. (1999). Tuning into future healthcare use of RFID. Automatic I.D. News, 15(2), 58.

Mooney, J.G., Gurbaxani, V. \& Kraemer, K.L. (1996). A process oriented framework for assessing the business value of information technology. The DATA Base for Advances in Information Systems, 27(2), 68-81. 
Murphy, C. (2003). Deciding how to work with competitors. InformationWeek, November (962), 73.

Ngai, E.W.T., Moon, K., Riggins, F. \& Yi, C. (2008). RFID research: An academic literature review (1995-2005) and future research directions. International Journal of Production Economics, 112(2), 510-520.

NIST (2009). National Institute of Standards and Technology, Baldrige National Quality Program Health Care Criteria for Performance Excellence, Gaithersburg, MD.

Nunnally, J. (1978). Psychometric Theory. New York, NY: McGraw-Hill.

O'Connor, M. C. (2005). Suppliers meet mandate frugally. RFID Journal, January 3, accessed March 22, 2005, available at http://www.rfidjournal.com/article/articleview/1308/1/1/

Parks, I. (2003). New microchip watchdog could boost patient compliance. Drug Store News, 25(7), 26.

Rekik, Y., Sahin, E. \& Dallery, Y. (2008). Analysis of the impact of the RFID technology on reducing product misplacement errors at retail stores. International Journal of Production Economics, 112(1), 264-278.

Reyes, P.M., \& Frazier, G. (2007). Radio frequency identification: past, present and future business applications. International Journal of Integrated Supply Management, 3(2), 125134.

Reyes, P.M., Frazier, G., Prater, E., \& Cannon, A. (2007). RFID: the state of the union between promise and practice. International Journal of Integrated Supply Management, 3(2), 192206.

Roberts, S. (2003). When the supply chain becomes a matter of life and death. Frontline Solutions (Pan-European Edition), 12(2), 14-16.

Rogoski, R. (2006). On track. Health Management Technology, 27(1), 12-18.

Sarac, A., Absi, N., \& Dauzere-Pérès, S. (2010). A literature review on the impact of RFID technologies on supply chain management. International Journal of Production Economics, 128(1), 77-95.

Schwaitzberg, S. (2006). The emergence of radio frequency identification tags: applications in surgery. Surgical Endoscopy, 20(8), 1315-1319.

Segars, A.H., \& Grover, V. (1993). Re-examining perceived ease of use and usefulness: a confirmatory factor analysis. MIS Quarterly, 17(4), 517-525.

Sethi, V., \& King, W.R. (1994). Development of measures to assess the extent to which an information technology application provides competitive advantage. Management Science, 40(12), 1601-1627.

Srivastava, B. (2004). Radio frequency ID technology: the next revolution in SCM. Business Horizons, 47(6), 60-68.

Tang, P. \& Lansky, D. (2005). The missing link: Bridging the patient-provider health information gap. Health Affairs, 24(5), 1290-1296. 
Tucker, A. (2004). The impact of operational failures on hospital nurses and their patients. Journal of Operations Management, 22(2), 151-169.

Tzeng, S.F., Chen, W.-H., \& Pai, F.-Y., (2008). Evaluating the business value of RFID: Evidence from 5 case studies. International Journal of Production Economics, 112(2), 601613.

Uckun, C., Karaesman, F. \& Savas, S. (2008). Investment in improved inventory accuracy in a decentralized supply chain. International Journal of Production Economics, 113(2), 546-566.

Umble, M., \& Umble, E. (2006). Utilizing buffer management to improve performance in a health care environment. European Journal of Operational Research, 174(2), 1060-1075.

Vijayaraman, B., \& Osyk, B. (2006). An empirical study of RFID implementation in the warehousing industry. The International Journal of Logistics Management, 17(1), 6-20.

Visich, J.K., Li, S., Khumawala, B.M. \& Reyes, P.M. (2009). Empirical evidence of RFID impacts on supply chain performance. International Journal of Operations \& Production Management, 29(12), 1290-1315.

Werts, C.E., Linn, R.L., \& Joreskog, K.G. (1974). Interclass reliability estimates: testing structural assumptions. Educational and Psychological Measurement, 34, 25-33.

Wicks, A.M., Visich, J.K., \& Li, S. (2006). Radio frequency identification applications in health care. International Journal of Healthcare Technology and Management, 7(6), 522-540.

Wright, K., Bretthauer, K., \& Côté, M. (2006). Reexamining the nurse scheduling problem: staffing ratios and nursing shortages. Decision Sciences, 37(1), 39-70. 


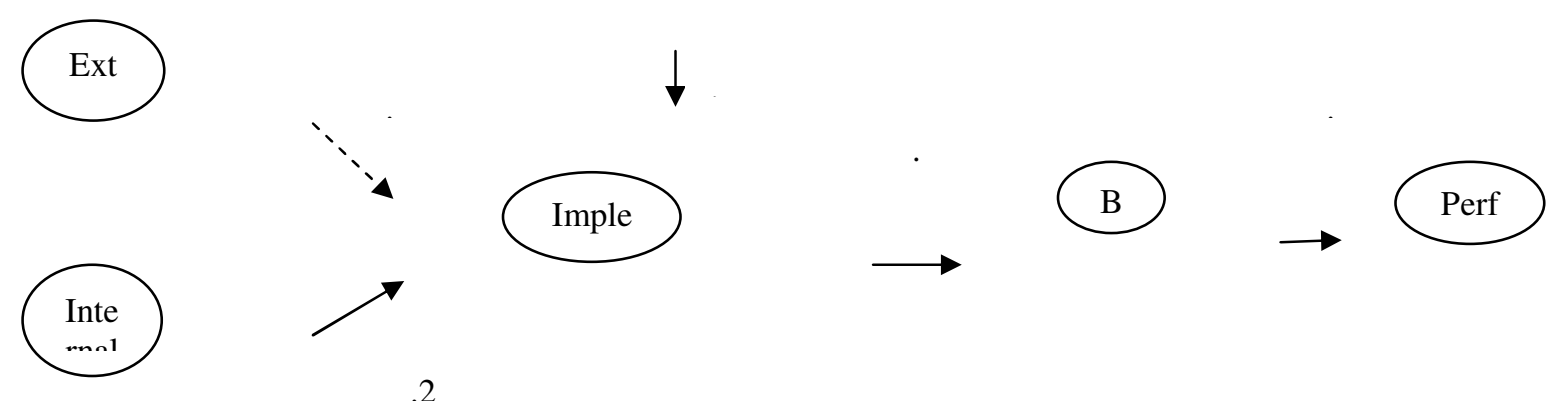

Figure 1: Antecedents and Consequences of RFID Implementation in Health Care Organizations

Note: Solid lines are for significant paths; dashed lines indicate insignificant paths; t-values are in parentheses.

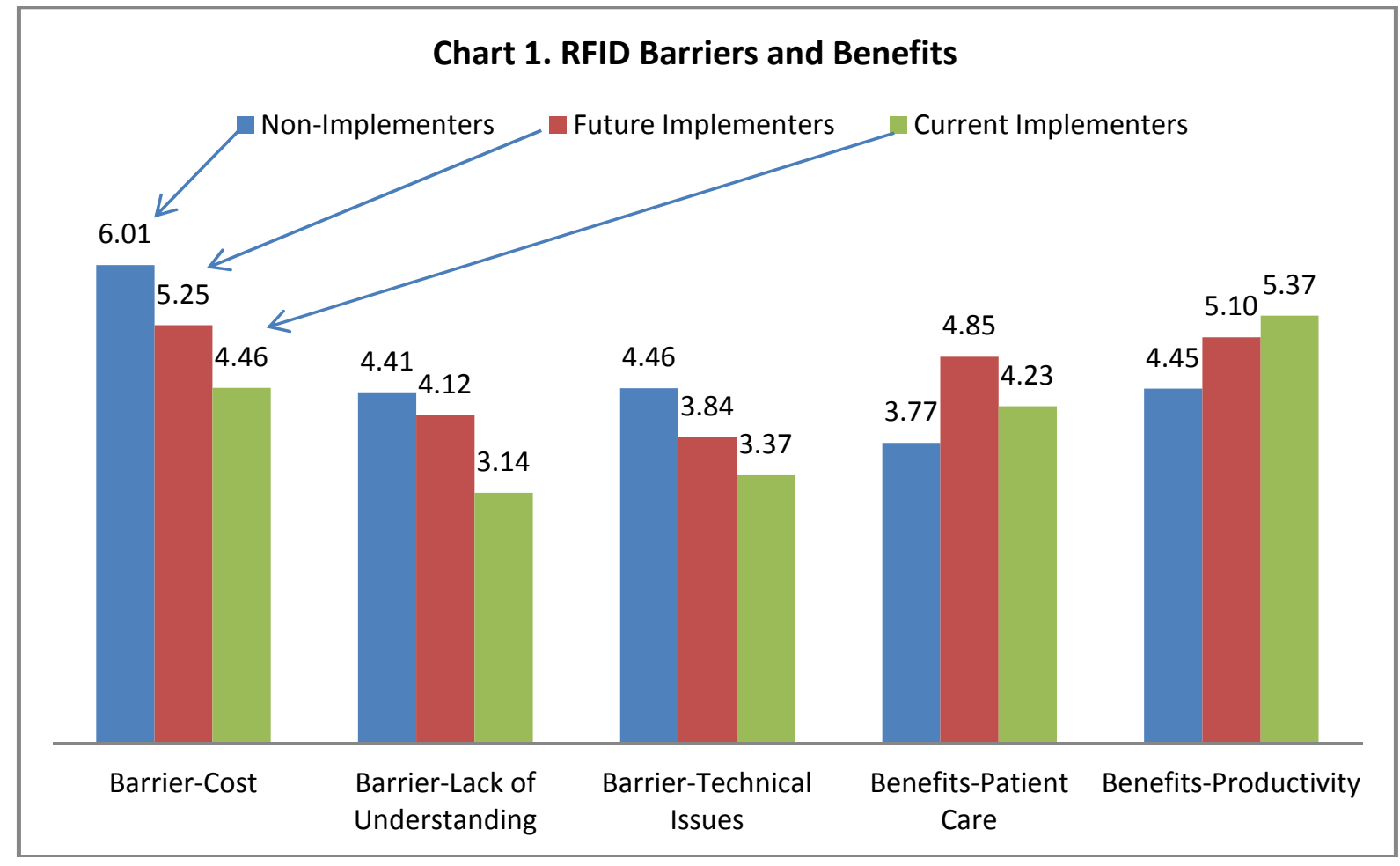


Table 1: Constructs for RFID in Health Care

\begin{tabular}{|c|c|c|}
\hline Constructs & Definitions & Literature \\
\hline Drivers & $\begin{array}{l}\text { The level of pressure externally and internally to } \\
\text { adopt RFID in order to improve a wide range of } \\
\text { hospital process outcomes. }\end{array}$ & $\begin{array}{l}\text { FDA (2004), Vijayaraman and Osyk } \\
(2006), \text { Wicks et al. }(2006), \text { Reyes } \text { et al. } \\
(2007), \text { Correa et al. }(2007), \text { Li et al. } \\
(2010)\end{array}$ \\
\hline $\begin{array}{l}\text { Implementation } \\
\text { Level }\end{array}$ & $\begin{array}{l}\text { The process area within the hospital that RFID is } \\
\text { implemented. This includes clinical processes } \\
\text { that directly impact the patient and administrative } \\
\text { processes that indirectly impact the patient. }\end{array}$ & $\begin{array}{l}\text { Li and Collier (2000), Marley et al. } \\
\text { (2004), Wicks et al. (2006), Correa et al. } \\
\text { (2007), Schwaitzberg (2006), Janz et al. } \\
\text { (2007), Chao et al. (2007) }\end{array}$ \\
\hline Barriers & $\begin{array}{l}\text { The extent to which possible obstacles reject or } \\
\text { delay the implementation of RFID including cost, } \\
\text { a lack of understanding, technical issues, and } \\
\text { privacy concerns. }\end{array}$ & $\begin{array}{l}\text { Srivastava (2004), Li and Visich (2006), } \\
\text { Vijayaraman and Osyk (2006), HHS } \\
\text { (2006) Wicks et al. (2006), Reyes et al. } \\
\text { (2007), Li et al. (2010), Reyes and } \\
\text { Frazier (2007), Correa et al. (2007) }\end{array}$ \\
\hline Benefits & $\begin{array}{l}\text { The level of benefits that hospitals can receive } \\
\text { from RFID implementation including the areas of } \\
\text { patient care, productivity, security and safety, } \\
\text { asset management, communication, and } \\
\text { employees. }\end{array}$ & $\begin{array}{l}\text { Srivastava (2004), Li and Visich (2006), } \\
\text { Vijayaraman and Osyk (2006), HHS } \\
\text { (2006) Wicks et al. (2006), Reyes et al. } \\
\text { (2007), Li et al. (2010), Reyes and } \\
\text { Frazier (2007), Chao et al. (2007), } \\
\text { Correa et al. (2007) }\end{array}$ \\
\hline Performance & $\begin{array}{l}\text { The performance position of the hospital with } \\
\text { respect to their competitors in the areas of cost, } \\
\text { quality, and finances. }\end{array}$ & $\begin{array}{l}\mathrm{Li}(1997), \mathrm{Li} \text { and Collier (2000), Meyer } \\
\text { and Collier (2001), Li et al. (2002), Li } \\
\text { and Benton (2003, 2006), Marley et al. } \\
(2004),\end{array}$ \\
\hline
\end{tabular}

Table 2: Barriers to the Implementation of RFID

\begin{tabular}{|c|c|c|c|c|c|c|c|c|c|c|}
\hline & $\begin{array}{l}\text { Paper } \\
\text { Type* }\end{array}$ & $\begin{array}{l}\text { Universal } \\
\text { Standards }\end{array}$ & Cost & $\begin{array}{c}\text { Software } \\
\text { Applications }\end{array}$ & $\begin{array}{l}\text { Technology } \\
\text { Problems }\end{array}$ & Privacy & Security & Environmental & $\begin{array}{c}\text { Lack of } \\
\text { Understanding }\end{array}$ & Labeling \\
\hline $\begin{array}{l}\text { Srivastava } \\
\text { (2004) }\end{array}$ & SCO & $\mathrm{X}$ & $\mathrm{X}$ & $\mathrm{X}$ & $\mathrm{X}$ & $\mathrm{X}$ & & & & \\
\hline $\begin{array}{l}\text { Li \& Visich } \\
(2006)\end{array}$ & SCO & $\mathrm{X}$ & $\mathrm{X}$ & $\mathrm{X}$ & $\mathrm{X}$ & $\mathrm{X}$ & $\mathrm{X}$ & $\mathrm{X}$ & & \\
\hline $\begin{array}{l}\text { Reyes \& } \\
\text { Frazier } \\
(2007)\end{array}$ & SCO & $\mathrm{X}$ & $\mathrm{X}$ & & $\mathrm{X}$ & $\mathrm{X}$ & & & & \\
\hline $\begin{array}{l}\text { Vijayaraman } \\
\& \\
\text { Osyk (2006) }\end{array}$ & SCS & $\mathrm{X}$ & $\mathrm{X}$ & $\mathrm{X}$ & & $\mathrm{X}$ & $\mathrm{X}$ & & $\mathrm{X}$ & \\
\hline $\begin{array}{l}\text { Reyes } \text { et al. } \\
(2007)\end{array}$ & SCS & $\mathrm{X}$ & $\mathrm{X}$ & & $\mathrm{X}$ & & $\mathrm{X}$ & & & \\
\hline $\begin{array}{l}\text { Li et al. } \\
(2010)\end{array}$ & SCS & $\mathrm{X}$ & $\mathrm{X}$ & $\mathrm{X}$ & $\mathrm{X}$ & $\mathrm{X}$ & $\mathrm{X}$ & $\mathrm{X}$ & $\mathrm{X}$ & \\
\hline $\begin{array}{l}\text { Wicks et al. } \\
(2006)\end{array}$ & $\mathrm{HCO}$ & $\mathrm{X}$ & $\mathrm{X}$ & $\mathrm{X}$ & $\mathrm{X}$ & $\mathrm{X}$ & $\mathrm{X}$ & & & $\bar{X}$ \\
\hline $\begin{array}{l}\text { Correa et al. } \\
(2007)\end{array}$ & $\mathrm{HCO}$ & $\mathrm{X}$ & $\mathrm{X}$ & $\mathrm{X}$ & $\mathrm{X}$ & $\mathrm{X}$ & $\mathrm{X}$ & & & \\
\hline
\end{tabular}

*SCO: supply chain overview; SCS: supply chain survey; HCO: health care overview 
Table 3: Benefits from the Implementation of RFID

\begin{tabular}{|l|c|c|c|c|c|c|c|c|}
\hline & $\begin{array}{c}\text { Paper } \\
\text { Type* }\end{array}$ & $\begin{array}{c}\text { Track/ } \\
\text { Trace }\end{array}$ & Inventory & Efficiency & Communication & $\begin{array}{c}\text { Asset } \\
\text { Mgmt. }\end{array}$ & $\begin{array}{c}\text { Error } \\
\text { Reduction }\end{array}$ & $\begin{array}{c}\text { Patient } \\
\text { Care }\end{array}$ \\
\hline $\begin{array}{l}\text { Srivastava } \\
(2004)\end{array}$ & SCO & $\mathrm{X}$ & $\mathrm{X}$ & $\mathrm{X}$ & $\mathrm{X}$ & $\mathrm{X}$ & & \\
\hline $\begin{array}{l}\text { Li \& Visich } \\
(2006)\end{array}$ & $\mathrm{SCO}$ & $\mathrm{X}$ & $\mathrm{X}$ & $\mathrm{X}$ & $\mathrm{X}$ & $\mathrm{X}$ & & \\
\hline $\begin{array}{l}\text { Reyes \& } \\
\text { Frazier } \\
(2007)\end{array}$ & $\mathrm{SCO}$ & $\mathrm{X}$ & $\mathrm{X}$ & $\mathrm{X}$ & & & & \\
\hline $\begin{array}{l}\text { Vijayaraman } \\
\text { \& Osyk } \\
(2006)\end{array}$ & $\mathrm{SCS}$ & $\mathrm{X}$ & $\mathrm{X}$ & $\mathrm{X}$ & & $\mathrm{X}$ & & \\
\hline $\begin{array}{l}\text { Reyes } \text { et al. } \\
(2007)\end{array}$ & $\mathrm{SCS}$ & $\mathrm{X}$ & $\mathrm{X}$ & $\mathrm{X}$ & $\mathrm{X}$ & $\mathrm{X}$ & $\mathrm{X}$ & $\mathrm{X}$ \\
\hline $\begin{array}{l}\text { Li } \text { et al. } \\
(2010)\end{array}$ & $\mathrm{SCS}$ & $\mathrm{X}$ & $\mathrm{X}$ & $\mathrm{X}$ & & & $\mathrm{X}$ & \\
\hline $\begin{array}{l}\text { Wicks } \text { et al. } \\
(2006)\end{array}$ & $\mathrm{HCO}$ & $\mathrm{X}$ & $\mathrm{X}$ & $\mathrm{X}$ & $\mathrm{X}$ & $\mathrm{X}$ & $\mathrm{X}$ & $\mathrm{X}$ \\
\hline $\begin{array}{l}\text { Correa } \text { et al. } \\
(2007)\end{array}$ & $\mathrm{HCO}$ & $\mathrm{X}$ & $\mathrm{X}$ & $\mathrm{X}$ & $\mathrm{X}$ & $\mathrm{X}$ & & $\mathrm{X}$ \\
\hline $\begin{array}{l}\text { Sarac et al. } \\
(2010)\end{array}$ & $\mathrm{SCO}$ & $\mathrm{X}$ & $\mathrm{X}$ & $\mathrm{X}$ & & & $\mathrm{X}$ & \\
\hline
\end{tabular}

*SCO: supply chain overview; SCS: supply chain survey; HCO: health care overview

Table 4: Demographic Data for the Respondents (sample size 88)

\begin{tabular}{|c|c|c|}
\hline & Number & Percentage \\
\hline \multicolumn{3}{|l|}{ Job Title (88) } \\
\hline CEO & 27 & $30.7 \%$ \\
\hline $\mathrm{VP}$ & 17 & $19.3 \%$ \\
\hline Director & 25 & $28.4 \%$ \\
\hline Manager & 10 & $11.4 \%$ \\
\hline $\mathrm{CFO}$ & 1 & $1.1 \%$ \\
\hline $\mathrm{CNO}$ & 1 & $1.1 \%$ \\
\hline $\mathrm{CIO}$ & 3 & $3.4 \%$ \\
\hline $\mathrm{COO}$ & 2 & $2.3 \%$ \\
\hline Other & 2 & $2.3 \%$ \\
\hline \multicolumn{3}{|c|}{ Number of Employees (86) } \\
\hline Under 100 & 2 & $2.2 \%$ \\
\hline 101 and 250 & 13 & $14.8 \%$ \\
\hline 251 and 500 & 13 & $14.8 \%$ \\
\hline 500 and 1000 & 19 & $21.6 \%$ \\
\hline Above 1000 & 39 & $44.3 \%$ \\
\hline \multicolumn{3}{|c|}{ Number of Beds Available (87) } \\
\hline Under 100 & 28 & $32.2 \%$ \\
\hline 101 and 250 & 28 & $32.2 \%$ \\
\hline 251 and 500 & 12 & $13.8 \%$ \\
\hline 500 and 1000 & 12 & $13.8 \%$ \\
\hline Above 1000 & 7 & $8.0 \%$ \\
\hline \multicolumn{3}{|c|}{ Hospital Location (86) } \\
\hline Urban & 40 & $46.5 \%$ \\
\hline Rural & 46 & $53.5 \%$ \\
\hline \multicolumn{3}{|c|}{ Teaching Hospital (87) } \\
\hline Yes & 21 & $24.1 \%$ \\
\hline No & 66 & $75.9 \%$ \\
\hline \multicolumn{3}{|c|}{ For Profit or not-for-profit (85) } \\
\hline For Profit & 6 & $7.1 \%$ \\
\hline Not-for-profit & 79 & $92.9 \%$ \\
\hline \multicolumn{3}{|c|}{ System-affiliated or stand-alone (87) } \\
\hline System affiliated & 49 & $56.3 \%$ \\
\hline Stand-alone & 38 & $43.7 \%$ \\
\hline
\end{tabular}


Table 5: Assessment of Unidimensionality

\begin{tabular}{|c|c|c|c|c|c|c|}
\hline Construct & Sub-Construct & Indicators & $\chi^{2}$ & $\begin{array}{c}\mathrm{P} \\
\text { value }\end{array}$ & GFI & CFI \\
\hline \multirow[t]{2}{*}{ Drivers } & External Drivers (ED) & 6 & 30.05 & .00 & .89 & .95 \\
\hline & Internal Drivers (ID) & 8 & 75.38 & .00 & .83 & .90 \\
\hline \multirow[t]{2}{*}{ Implementation Level } & Clinical Focus $(\mathrm{CF})$ & 8 & 32.00 & .00 & .85 & .95 \\
\hline & Administrative Focus (AF) & 6 & 37.36 & .00 & .88 & .94 \\
\hline \multirow[t]{4}{*}{ Barriers } & Cost Issues (CI) & 5 & 29.18 & .00 & .88 & .90 \\
\hline & Lack of Understanding (LU) & 8 & 66.30 & .00 & .86 & .93 \\
\hline & Technical Issues (TI) & 4 & 1.07 & .58 & .99 & .99 \\
\hline & Privacy and Security Concerns (PSC) & 5 & 41.71 & .00 & .87 & .94 \\
\hline \multirow[t]{5}{*}{ Benefits } & Patient Care (PC) & 5 & 19.78 & .00 & .91 & .95 \\
\hline & Productivity (PD) & 4 & 7.45 & .02 & .96 & .98 \\
\hline & Security and Safety (SS) & 4 & 67.10 & .00 & .99 & .99 \\
\hline & Asset Management (AM) & 4 & 26.90 & .00 & .87 & .95 \\
\hline & Communication (COM) & 3 & 11.67 & .55 & .96 & 1.00 \\
\hline \multirow[t]{3}{*}{ Performance } & Cost Performance $(\mathrm{CP})$ & 3 & 30.83 & .00 & .91 & .97 \\
\hline & Quality Performance (QP) & 4 & 15.47 & .00 & .92 & .95 \\
\hline & Financial Performance (FP) & 4 & 2.89 & .24 & .99 & .99 \\
\hline
\end{tabular}

Note: the model fit statistics could not be obtained for the constructs with three items. In these cases, a two-factor model was tested by adding the items of another construct.

Table 6: Assessment of Reliability

\begin{tabular}{|l|c|c|c|}
\hline Sub-Construct & Indicators & Reliability $\left(\rho_{\mathrm{c}}\right)$ & Reliability $(\alpha)$ \\
\hline External Drivers (ED) & 6 & .92 & .92 \\
\hline Internal Drivers (ID) & 8 & .93 & .92 \\
\hline Clinical Focus (CF) & 8 & .96 & .96 \\
\hline Administrative Focus (AF) & 6 & .94 & .93 \\
\hline Cost Issues (CI) & 5 & .85 & .86 \\
\hline Lack of Understanding (LU) & 8 & .95 & .95 \\
\hline Technical Issues (TI) & 4 & .91 & .90 \\
\hline Privacy and Security Concerns (PSC) & 5 & .97 & .97 \\
\hline Patient Care (PC) & 5 & .92 & .92 \\
\hline Productivity (PD) & 4 & .92 & .92 \\
\hline Security and Safety (SS) & 4 & .94 & .94 \\
\hline Asset Management (AM) & 4 & .97 & .97 \\
\hline Communication (COM) & 3 & .95 & .95 \\
\hline Cost Performance (CP) & 3 & .88 & .87 \\
\hline Quality Performance (QP) & 4 & .91 & .91 \\
\hline Financial Performance (FP) & 4 & .94 & .93 \\
\hline \hline
\end{tabular}


Table 7: Factor Analysis for Drivers

\begin{tabular}{|c|c|c|}
\hline Item & $\begin{array}{l}\text { Internal } \\
\text { Drivers }\end{array}$ & $\begin{array}{c}\text { External } \\
\text { Drivers }\end{array}$ \\
\hline ID9 & .880 & \\
\hline ID7 & .872 & \\
\hline ID2 & .861 & \\
\hline ID8 & .859 & \\
\hline ID3 & .785 & \\
\hline ID1 & .757 & \\
\hline ID4 & .735 & \\
\hline ID10 & .706 & \\
\hline ID5 & .700 & \\
\hline ED3 & & .921 \\
\hline ED5 & & .908 \\
\hline ED4 & & .868 \\
\hline ED2 & & .797 \\
\hline ED1 & & .779 \\
\hline ED6 & & .715 \\
\hline Eigenvalue & 7.19 & 3.16 \\
\hline$\%$ of Variance & 47.93 & 21.06 \\
\hline $\begin{array}{c}\text { Cumulative } \% \text { of } \\
\text { variance }\end{array}$ & 47.93 & 69.00 \\
\hline
\end{tabular}

Table 8: Factor Analysis for Implementation Level

\begin{tabular}{|c|c|c|}
\hline Item & $\begin{array}{c}\text { Clinical } \\
\text { Focus }\end{array}$ & $\begin{array}{l}\text { Administrative } \\
\text { Focus }\end{array}$ \\
\hline CF3 & .860 & \\
\hline CF4 & .825 & \\
\hline CF7 & .812 & \\
\hline $\mathrm{CF} 2$ & .802 & \\
\hline CF9 & .798 & .422 \\
\hline CF6 & .797 & .454 \\
\hline CF5 & .796 & \\
\hline CF10 & .762 & .407 \\
\hline AF5 & .421 & .535 \\
\hline AF4 & & .884 \\
\hline AF3 & & .874 \\
\hline AF2 & & .839 \\
\hline AF6 & & .818 \\
\hline $\mathrm{AF} 1$ & .488 & .604 \\
\hline Eigenvalue & 9.95 & 1.18 \\
\hline$\%$ of Variance & 71.06 & 8.46 \\
\hline $\begin{array}{c}\text { Cumulative } \% \text { of } \\
\text { variance }\end{array}$ & 71.06 & 79.52 \\
\hline
\end{tabular}


Table 9: Factor Analysis for Barriers

\begin{tabular}{|c|c|c|c|c|}
\hline & Lack of Understanding & $\begin{array}{c}\text { Privacy and Security } \\
\text { Concerns }\end{array}$ & Cost Issues & Technical Issues \\
\hline LU5 & 0.849 & & & \\
\hline LU2 & 0.814 & & & \\
\hline LU4 & 0.807 & & & \\
\hline LU3 & 0.787 & & & \\
\hline LU1 & 0.765 & & & \\
\hline LU6 & 0.764 & & & \\
\hline LU7 & 0.728 & & & \\
\hline LU8 & 0.702 & & & \\
\hline PSC5 & & 0.922 & & \\
\hline $\mathrm{PSC} 4$ & & 0.915 & & \\
\hline PSC6 & & 0.889 & & \\
\hline $\mathrm{PSC} 2$ & & 0.872 & & \\
\hline PSC1 & & 0.850 & & \\
\hline $\mathrm{CI} 1$ & & & 0.880 & \\
\hline $\mathrm{CI} 2$ & & & 0.862 & \\
\hline $\mathrm{CI} 3$ & & & 0.832 & \\
\hline CI6 & & & 0.764 & \\
\hline $\mathrm{CI} 4$ & & & 0.487 & \\
\hline TI2 & & & & 0.901 \\
\hline TI1 & & & & 0.836 \\
\hline TI3 & & & & 0.833 \\
\hline TI7 & & & & 0.602 \\
\hline Eigenvalue & 10.23 & 2.72 & 2.47 & 1.65 \\
\hline$\%$ of Variance & 46.48 & 12.34 & 11.22 & 7.49 \\
\hline Cumulative $\%$ of variance & 46.48 & 58.82 & 70.04 & 77.53 \\
\hline
\end{tabular}


Table 10: Factor Analysis for Benefits

\begin{tabular}{|c|c|c|c|c|c|}
\hline Item & Security and Safety & Asset Management & Productivity & Patient Care & Communication \\
\hline SS1 & .847 & & & & \\
\hline SS4 & .830 & & & & \\
\hline SS5 & .802 & & & & \\
\hline SS3 & .777 & & & & \\
\hline AM2 & & .950 & & & \\
\hline AM3 & & .948 & & & \\
\hline AM1 & & .926 & & & \\
\hline AM4 & & .881 & & & \\
\hline PD3 & & & .870 & & \\
\hline PD1 & & & .862 & & \\
\hline PD4 & & & .746 & & \\
\hline PD2 & & & .651 & & \\
\hline $\mathrm{PC} 2$ & & & & .792 & \\
\hline PC1 & & & & .755 & .416 \\
\hline PC7 & & & & .728 & \\
\hline PC3 & & & & .678 & \\
\hline COM1 & & & & & .785 \\
\hline COM2 & & & & & .777 \\
\hline COM3 & & & & & .742 \\
\hline Eigenvalue & 10.20 & 3.12 & 1.44 & 1.08 & 0.80 \\
\hline$\%$ of Variance & 19.95 & 19.94 & 17.09 & 15.98 & 14.59 \\
\hline Cumulative $\%$ of variance & 19.95 & 39.89 & 56.98 & 72.96 & 87.55 \\
\hline
\end{tabular}

Table 11: Factor Analysis for Performance

\begin{tabular}{|c|c|c|c|}
\hline & Financial Performance & Quality Performance & Cost Performance \\
\hline FP2 & .907 & & \\
\hline FP3 & .875 & & \\
\hline FP4 & .824 & & \\
\hline FP1 & .820 & & \\
\hline $\mathrm{QP} 2$ & & .901 & \\
\hline QP4 & & .879 & \\
\hline QP3 & & .832 & \\
\hline QP1 & & .801 & \\
\hline $\mathrm{CP} 1$ & & & .891 \\
\hline $\mathrm{CP} 2$ & & & .887 \\
\hline $\mathrm{CP} 3$ & .477 & & .748 \\
\hline Eigenvalue & 5.829 & 1.955 & 1.292 \\
\hline$\%$ of Variance & 31.311 & 29.165 & 22.036 \\
\hline Cumulative $\%$ of variance & 31.311 & 60.476 & 82.512 \\
\hline
\end{tabular}


Table 12 RFID Applications between Future Implementers and Current Implementers

\begin{tabular}{|l|c|c|}
\hline & $\begin{array}{c}\text { Future } \\
\text { Implementers }\end{array}$ & $\begin{array}{c}\text { Current } \\
\text { Implementers }\end{array}$ \\
\hline Clinical Focus - direct impact on patient & \multicolumn{2}{|l|}{} \\
\hline Track infants & 4.16 & 3.20 \\
\hline Track surgical patients & 3.39 & 3.06 \\
\hline Track emergency room patients & 3.29 & 3.23 \\
\hline Track other patients & 3.16 & 2.83 \\
\hline Track medical equipment & 3.97 & 4.75 \\
\hline Track the blood supply & 3.22 & 2.60 \\
\hline Track patient medication usage & 3.61 & 3.17 \\
\hline Track medication dispensing & 3.77 & 3.49 \\
\hline Track lab specimens & 3.42 & 2.77 \\
\hline Track surgical operations (tools, sponges etc) & 3.48 & 3.08 \\
\hline Administrative Focus - indirect impact on patient & \\
\hline Track administrative equipment & 2.45 & 3.19 \\
\hline Track nurses & 2.42 & 2.26 \\
\hline Track doctors & 1.81 & 2.00 \\
\hline Track administrative personnel & 1.74 & 1.84 \\
\hline Track hospital beds & 3.35 & 3.31 \\
\hline Track uniforms & 2.03 & 1.92 \\
\hline Track MRO inventories (maintenance, repair, & 2.84 & 3.45 \\
operating) & \multicolumn{2}{|l}{} \\
\hline
\end{tabular}


Table 13 ANOVA tests on RFID Drivers and Barriers

\begin{tabular}{|c|c|c|c|c|c|}
\hline & Group & Number & Mean & F Value & Significance \\
\hline \multirow{3}{*}{$\begin{array}{l}\text { External } \\
\text { Drivers }\end{array}$} & Non-Implementers & 44 & 3.16 & \multirow{3}{*}{.71} & \multirow{3}{*}{.49} \\
\hline & Future Implementers & 31 & 3.11 & & \\
\hline & Current Implementers & 13 & 2.58 & & \\
\hline \multirow{3}{*}{$\begin{array}{l}\text { Internal } \\
\text { Drivers }\end{array}$} & Non-Implementers & 44 & 5.40 & \multirow{3}{*}{1.01} & \multirow{3}{*}{.37} \\
\hline & Future Implementers & 31 & 5.65 & & \\
\hline & Current Implementers & 13 & 5.94 & & \\
\hline \multirow{3}{*}{ Barriers-Cost } & Non-Implementers & 44 & 6.01 & \multirow{3}{*}{8.97} & \multirow{3}{*}{.00} \\
\hline & Future Implementers & 31 & 5.25 & & \\
\hline & Current Implementers & 13 & 4.46 & & \\
\hline \multirow{3}{*}{$\begin{array}{l}\text { Barriers-Lack } \\
\text { of } \\
\text { Understanding }\end{array}$} & Non-Implementers & 44 & 4.41 & \multirow{3}{*}{3.95} & \multirow{3}{*}{.02} \\
\hline & Future Implementers & 31 & 4.12 & & \\
\hline & Current Implementers & 13 & 3.14 & & \\
\hline \multirow{3}{*}{$\begin{array}{l}\text { Barriers- } \\
\text { Technical } \\
\text { Issues }\end{array}$} & Non-Implementers & 44 & 4.46 & \multirow{3}{*}{3.65} & \multirow{3}{*}{.03} \\
\hline & Future Implementers & 31 & 3.84 & & \\
\hline & Current Implementers & 13 & 3.37 & & \\
\hline \multirow{3}{*}{$\begin{array}{l}\text { Barriers- } \\
\text { Privacy \& } \\
\text { Security } \\
\text { Concern }\end{array}$} & Non-Implementers & 44 & 3.95 & \multirow{3}{*}{1.04} & \multirow{3}{*}{.36} \\
\hline & Future Implementers & 31 & 3.80 & & \\
\hline & Current Implementers & 13 & 3.20 & & \\
\hline
\end{tabular}


Table 14 ANOVA tests on RFID Benefits and Performance

\begin{tabular}{|c|c|c|c|c|c|}
\hline & Group & Number & Mean & F Value & Significance \\
\hline \multirow{3}{*}{$\begin{array}{l}\text { Benefits-Patient } \\
\text { Care }\end{array}$} & Non-Implementers & 44 & 3.77 & \multirow{3}{*}{4.13} & \multirow{3}{*}{.02} \\
\hline & Future Implementers & 31 & 4.85 & & \\
\hline & Current Implementers & 13 & 4.23 & & \\
\hline \multirow{3}{*}{$\begin{array}{l}\text { Benefits- } \\
\text { Productivity }\end{array}$} & Non-Implementers & 44 & 4.45 & \multirow{3}{*}{2.89} & \multirow{3}{*}{.06} \\
\hline & Future Implementers & 31 & 5.10 & & \\
\hline & Current Implementers & 13 & 5.37 & & \\
\hline \multirow{3}{*}{$\begin{array}{l}\text { Benefits- } \\
\text { Security and } \\
\text { Safety }\end{array}$} & Non-Implementers & 44 & 4.06 & \multirow{3}{*}{1.80} & \multirow{3}{*}{.17} \\
\hline & Future Implementers & 31 & 4.91 & & \\
\hline & Current Implementers & 13 & 4.46 & & \\
\hline \multirow{3}{*}{$\begin{array}{l}\text { Benefits-Asset } \\
\text { Management }\end{array}$} & Non-Implementers & 44 & 4.84 & \multirow{3}{*}{2.40} & \multirow{3}{*}{.10} \\
\hline & Future Implementers & 31 & 5.76 & & \\
\hline & Current Implementers & 13 & 5.37 & & \\
\hline \multirow{3}{*}{$\begin{array}{l}\text { Benefits- } \\
\text { Communication }\end{array}$} & Non-Implementers & 44 & 3.47 & \multirow{3}{*}{1.98} & \multirow{3}{*}{.14} \\
\hline & Future Implementers & 31 & 4.29 & & \\
\hline & Current Implementers & 13 & 4.12 & & \\
\hline \multirow{3}{*}{$\begin{array}{l}\text { Performance- } \\
\text { Cost }\end{array}$} & Non-Implementers & 44 & 4.48 & \multirow{3}{*}{1.47} & \multirow{3}{*}{.23} \\
\hline & Future Implementers & 31 & 4.60 & & \\
\hline & Current Implementers & 13 & 3.97 & & \\
\hline \multirow{3}{*}{$\begin{array}{l}\text { Performance- } \\
\text { Quality }\end{array}$} & Non-Implementers & 44 & 5.01 & \multirow{3}{*}{.10} & \multirow{3}{*}{.91} \\
\hline & Future Implementers & 31 & 4.98 & & \\
\hline & Current Implementers & 13 & 5.12 & & \\
\hline \multirow{3}{*}{$\begin{array}{l}\text { Performance- } \\
\text { Financial }\end{array}$} & Non-Implementers & 44 & 4.33 & \multirow{3}{*}{.62} & \multirow{3}{*}{.54} \\
\hline & Future Implementers & 31 & 4.64 & & \\
\hline & Current Implementers & 13 & 4.46 & & \\
\hline
\end{tabular}


Table 15. T-tests on RFID Barriers and Benefits

\begin{tabular}{|l|l|c|c|}
\hline \multicolumn{1}{|c|}{ Group } & \multicolumn{1}{|c|}{ Construct } & t-Value & Significance \\
\hline \multirow{4}{*}{$\begin{array}{l}\text { Between Non- } \\
\text { Implementers and Future }\end{array}$} & Barriers-Cost & 2.76 & $\mathbf{. 0 1}$ \\
\cline { 2 - 4 } Implementers & $\begin{array}{l}\text { Barriers-Lack of } \\
\text { Understanding }\end{array}$ & .85 & .40 \\
\cline { 2 - 4 } & Barriers- Technical Issues & 1.87 & $\mathbf{. 0 7}$ \\
\cline { 2 - 4 } & Benefits-Patient Care & -2.93 & $\mathbf{. 0 0}$ \\
\cline { 2 - 4 } & Benefits-Productivity & -1.87 & $\mathbf{. 0 7}$ \\
\hline \hline \multirow{4}{*}{$\begin{array}{l}\text { Implementers and } \\
\text { Current Implementers }\end{array}$} & Barriers-Cost & 3.72 & $\mathbf{. 0 0}$ \\
\cline { 2 - 4 } & Barriers-Lack of & 2.64 & $\mathbf{. 0 1}$ \\
\cline { 2 - 4 } & Understanding & & \\
\cline { 2 - 4 } & Barriers- Technical Issues & 2.23 & $\mathbf{. 0 3}$ \\
\cline { 2 - 4 } & Benefits-Patient Care & -.83 & .41 \\
\cline { 2 - 4 } & Benefits-Productivity & -1.82 & $\mathbf{. 0 7}$ \\
\hline \multirow{4}{*}{$\begin{array}{l}\text { Between Future } \\
\text { Current Implementers }\end{array}$} & Barriers-Cost & 1.95 & $\mathbf{. 0 6}$ \\
\cline { 2 - 4 } & Barriers-Lack of & 2.31 & $\mathbf{. 0 3}$ \\
& Understanding & 1.16 & .25 \\
\cline { 2 - 4 } & Barriers- Technical Issues & 1.30 & .20 \\
\cline { 2 - 4 } & Benefits-Patient Care & .50 \\
\cline { 2 - 4 } & Benefits-Productivity & -.68 & \\
\hline
\end{tabular}




\section{Appendix A. Items for Drivers, Implementation Level, Barriers, Benefits, and Performance}

(Items marked by an asterisk were removed in the final instrument)

\section{Drivers}

Please rate the importance of the following drivers of implementing RFID. $(1=$ not important; $4=$ somewhat important; 7 = very important)

\section{Drivers-External Drivers $(\mathrm{ED})$}

ED1 Pressure from patients.

ED2 Pressure from suppliers.

ED3 Pressure from FDA.

ED4 Pressure from insurance companies and HMOs.

ED5 Pressure from external regulatory groups.

ED6 Keep up with competitors.

\section{Drivers-Internal Drivers (ID)}

ID1 Improve patient care.

ID2 Improve hospital productivity.

ID3 Improve hospital and patient security and safety.

ID4 Improve hospital asset management.

ID5* Improve hospital and patient communication.

ID6 Improve hospital employee job satisfaction.

ID7* Improve hospital cost performance.

ID8 Improve hospital quality performance.

ID9 Improve hospital financial performance.

ID10 Improve hospital supply chain performance.

\section{Implementation Level}

Please indicate the level of RFID implementation in your hospital in the following areas. $(1=$ no implementation; 4 $=$ moderate implementation; 7 = strong implementation)

\section{Implementation Level-Clinical Focus $(\mathrm{CF})$}

CF1* Track infants.

CF2 Track surgical patients.

CF3 Track emergency room patients.

CF4 Track other patients.

CF5 Track medical equipment.

CF6 Track the blood supply.

CF7 Track patient medication usage.

CF8* Track medication dispensing.

CF9 Track lab specimens.

CF10 Track surgical operations (tools, sponges etc).

\section{Implementation Level-Administrative Focus (AF)}

AF1 Track administrative equipment.

AF2 Track nurses.

AF3 Track doctors.

AF4 Track administrative personnel.

AF5 Track hospital beds.

AF6 Track uniforms.

AF7* Track MRO inventories (maintenance, repair, operating). 


\section{Barriers}

Please indicate the significance of the following barriers to implementing RFID in your hospital. $(1=$ no a barrier; 4 $=$ minor barrier; 7 = major barrier)

\section{Barriers-Cost Issues (CI)}

CI1 Cost of tags.

CI2 Cost of readers.

CI3 Initial cost of implementation.

CI4 Return on investment.

CI5* Payback period.

CI6 Lack of funds for the RFID implementation.

\section{Barriers-Lack of Understanding $(L U)$}

LU1 Your hospital's lack of knowledge/understanding about RFID.

LU2 Difficulty in understanding potential benefits.

LU3 Developing/integrating new process.

LU4 Determining potential costs.

LU5 Determining potential ROI.

LU6 Training problems.

LU7 Security/regulation issues.

LU8 Large number of stakeholders in the decision.

\section{Barriers-Technical Issues (TI)}

TI1 Technical issues with hardware.

TI2 Technical issues with software.

TI3 Analysis \& utilization of information generated from the RFID system.

TI4* Usage difficulties for patients.

TI5* Usage difficulties for suppliers.

TI6* Uncertainty of technology standards.

TI7 Database integration difficulty

\section{Barriers-Privacy and Security Concerns (PSC)}

PSC1 Privacy concerns that patients may have.

PSC2 Privacy concerns that employees may have.

PSC3* Privacy concerns of external entities.

PSC4 Security concerns about patient data integrity.

PSC5 Security concerns about employee data integrity.

PSC6 Security concerns about external entity data integrity.

\section{Benefits}

Please indicate the level of benefit your hospital may receive from implementing RFID. $(1=$ weak benefit; $4=$ moderate benefit; $7=$ strong benefit)

\section{Benefits-Patient Care $(P C)$}

PC1 Improve patient satisfaction with clinical processes.

PC2 Improve patient satisfaction with clinical outcomes.

PC3 Improve patient satisfaction with dispensing of medication.

PC4* Improve patients' compliance with medication prescriptions.

PC5* Improve patient safety.

PC6 Improve patient tracking.

PC7 Improve patient satisfaction with administrative processes. 


\section{Benefits-Productivity(PD)}

PD1 Improve efficiency of nurses.

PD2 Improve efficiency of physicians.

PD3 Improve support staff productivity.

PD4 Improve the efficiency of the treatment process.

\section{Benefits-Security and Safety(SS)}

SS1 Improve drug-handling safety.

$\mathrm{SS}_{2} * \quad$ Improve the safety of surgery.

SS3 Improve the security of medicine (theft prevention).

SS4 Reduce medical errors.

SS5 Improve the safety of the blood supply.

\section{Benefits-Asset Management(AM)}

AM1 Improve the tracking of medical equipment.

AM2 Improve the utilization and management of medical equipment.

AM3 Improve the preventive maintenance of equipment.

AM4 Reduce equipment rental costs and deferral of new purchases.

\section{Benefits-Communication(COM)}

COM1 Improve communication between hospital and patient.

COM2 Improve communication between hospital and patient's family.

COM3 Improve internal communication among hospital staff.

\section{Performance}

Please indicate the position of your hospital with respect to your competitors on the following dimensions of performance. ( 1 = significantly lower; 4 = equal; 7 = significantly higher $)$

\section{Performance-Cost Performance $(\mathrm{CP})$}

CP1 Holding down inpatient costs.

CP2 Attaining high labor productivity.

CP3 Maintaining high capacity utilization.

\section{Performance-Quality Performance(QP)}

QP1 Clinical quality.

QP2 Patient satisfaction.

QP3 Responding to patient requests.

QP4 Responding to patient complaints.

\section{Performance-Financial Performance(FP)}

FP1 Market share grow.

FP2 Return on assets.

FP3 Return on investment.

FP4 Operating profit. 